\title{
SOCIOLOGY OF MEDICINE: GENDER PROBLEMS OF THE COMPETITIVENESS OF WOMEN DENTISTS
}

\author{
EDITA MARGARYAN
}

\section{Introduction}

One of the traditional and at the same time topical issues of the sociology of medicine is the relationship between doctor and patient (including the context of their gender), which is considered as one of the most important factors of the effectiveness of the system of medical services. In addition, the very image of a doctor and his perception in society is among important directions of the sociology of medicine, which also intersects with economic sociology and the sociology of communications ${ }^{1}$.

The sociology of medicine studies the quality of medical services provided depending on the gender of doctors and patients, whether they have a certain stereotypical attitude towards representatives of their own and the opposite sex, the level of employment of women and men doctors, their distribution by areas and positions in the healthcare sector (in particular, on leadership positions), etc. ${ }^{2}$.

In particular, gender stereotypes in healthcare, as well as the impact of gender (doctors and patients) on the implementation of medical activities, is the subject area of the sociology of medicine ${ }^{3}$.

Modern medicine is developing in a society in which special attention is paid to the quality of services provided, including dental ones. However, despite the significant scientific and technological development of the industry, there are gender stereotypes that prevent the full realization of the possibilities of women dentists ${ }^{4}$. Today, according to statistics, about $68 \%$ of specialists working in dentistry are women, and therefore, the study of their professional activities, in our opinion, is especially important, since the level of qualifications and

${ }^{1} \mathrm{St}^{\prime}$ u Левина В. Н. Личностные качества врача в сотрудничестве с пациентом: учебное пособие. Ижевск, 2016, tr 60.; Батышев А. С. Врач + пациент: философия успеха // Батышев А. С., Батышева Т. Т. М.: ВК, 2011. Е2 521.

${ }^{2} \mathrm{St}^{\prime}$ u Курбатов А. В., Амлаев К. Р., Муравьев К. А. Современное состояние проблемы неравенства в здоровье: экологические, гендерные, экономические аспекты (обзор) // Наука. Инновации. Технологии. 2011, № 74, to 24-30.

${ }^{3} \mathrm{St}^{\prime}$ u Судьин, С. А. Гендерный аспект социологии медицины и здоровья // Женщина в российском обществе, 2012, № 4, 느 24-31.

${ }^{4} \mathrm{St}^{\prime}$ u Ковалева М. Д., Варгина С. А., Джерештиева М. Р. Гендерные особенности развития современной стоматологии // Социология медицины, 2009, № 1, ㄴ. 60-62; Нарчаев М. А., Меджидов М. Н. Оптимизация лечебной работы врача-стоматолога-терапевта на поликлиническом приеме // Вестник Дагестанской государственной медицинской академии, 2016, № 1(18), ㄴ, 71-74. 
quality of the services they provide, directly affect the development of this field of medicine in the whole. In particular, "female doctors believe that they understand patients better and are able to empathize with their needs better than men. Female dentists have no gender preference for their patients, but they find that they are more likely to deal with female patients than with men. Female doctors are convinced that patients of both sexes trust a female dentist more than a male doctor (58\%). Women dentists consider the professions of a dentist $(68 \%)$, pediatric dentist (74\%), and periodontist ( $82 \%$ ) to be purely female" ${ }^{2}$. Based on this, the analysis of gender balance in dentistry becomes relevant at all stages of the organization and the provision of dental services.

This study has been conducted to reveal the following aspects of the labor activity of female dentists: professional growth, education, advanced training, career, working conditions and their impact on health and psychological wellbeing, as well as the possibilities of increasing competitiveness and improving the quality of dental services.

\section{Research methodology}

This longitude study conducted in the period $2015-2017^{6}$, with further analysis, comparison, and reflection on the causes of the results. It involves 124 dentists - men and women aged 25 to 75 years, 62 men and 62 women working in Moscow (Russia) in various public and private medical organizations. To obtain objective information, the respondents filled out a semi-structured questionnaire.

The respondents indicated gender, age, marital status, specialization, sector of work (public or private medical organization), work experience in dentistry, work intensity, etc. The questionnaire also included questions that reveal the professional aspirations of dentists, the reason for choosing the particular specialization, gender perceptions, job satisfaction, general and dental health, and some other topics. The survey and medical examination were conducted anonymously.

\section{Results and discussion}

The group of respondents, men and women dentists of different gender, age, marital status, socio-economic status, professional qualifications, consisted of $82.3 \%$ of female dentists specializing in therapeutic dentistry, and $77,4 \%$ of male dentists as orthopedists. At the same time, the distribution of preferences among interns looked somewhat different: $35.5 \%$ of female interns would like to work in therapy, $43.5 \%$ in orthodontics, $6.5 \%$ in orthopedics, and $14.5 \%$ in surgery. Based on the data, many women dentists, most likely, do not work in the desired spe-

${ }^{5} \mathrm{St}_{i}^{\prime}$ u Ковалева М. Д., Барковская А. Ю. Гендерная проблематика в социологии медицины // Социология медицины, N 2, 2012, ㄴ. 17-18.

${ }^{6} \mathrm{St}^{\prime} \mathrm{u}$ A part of it is published in: Макеева И. М., Е.Г. Свистунова Е. Г., Маргарян Э. Г., Проценко А. С. Особенности трудовой деятельности и возможности профессионального роста врачей-стоматологов с учетом их гендерных различий // Стоматология. 2017, № 3, ta 49. 
cialization. Among the main reasons, dentists indicated the gender preferences of the employer in the allocation of vacancies, the employer's desire to hire experienced doctors, and the limited territorial choice of the clinic for women due to motherhood, proximity and working hours of child care facilities. However, the study shows that doctors themselves have gender stereotypes. Thus, among women, $14.5 \%$ of doctors considered their specialty to be "female" and $53.2 \%$ of men dentists, as "male". At the same time, representatives of different specialties highlighted the basic qualities necessary for successful work which turned out to be universal, such as professional skills, the possibility of advanced training, logical thinking, a predisposition to precise manual micromanipulations, perseverance and patience, a benevolent attitude towards patients.

Out of 124 respondents, $13 \%$ of women and $32.2 \%$ of men held administrative positions. At the same time, to the question: "what prevents a woman dentist from occupying a leadership position?", we received the following answers:

- $43.5 \%$ - "doing housework and raising children",

- $13 \%$ - "unwillingness to take on additional burden and responsibility",

- $34 \%$ did not see any obstacles and were not burdened with caring for young children.

At the same time, $21 \%$ of men and $27.4 \%$ of women had an academic degree. However, in the end, 9.5\% justified the indicated "obstacle" by the gender bias of the leadership.

The respondents were asked a question about the organizational and legal form of the medical organization in which they work. Of the respondents, $21.6 \%$ of female dentists work only in the public sector, $28.5 \%$ combine their work in the public and private sectors, and $50 \%$ work only in private organizations.

Men mostly work in the private sector (84\%), and only $16 \%$ combine work in the public and private sectors. This indicates a pronounced gender asymmetry in social and professional terms.

Women working in the public sector substantiate their choice with guaranteed wages and social guarantees of the state, which is especially important for women (doctors) with little children and those planning childbirth in the near future. The choice of the private sector is based on economic feasibility and professional comfort (modern equipment and dental materials of high-quality, opportunities for professional growth, and a high level of intercollegiate professional communication).

At the same time, almost all women working in the private sector of medical services, mention violation of women's rights by the employer regarding payment of benefits in for maternity, the absence of sick leave and vacation pay, which also confirms the existence of gender inequality in dentistry.

To gender and economically oriented question: "Does your income match your professional qualifications, profession, position, and employment?", we received the following answers (pic. 1): 

employment? (\%)

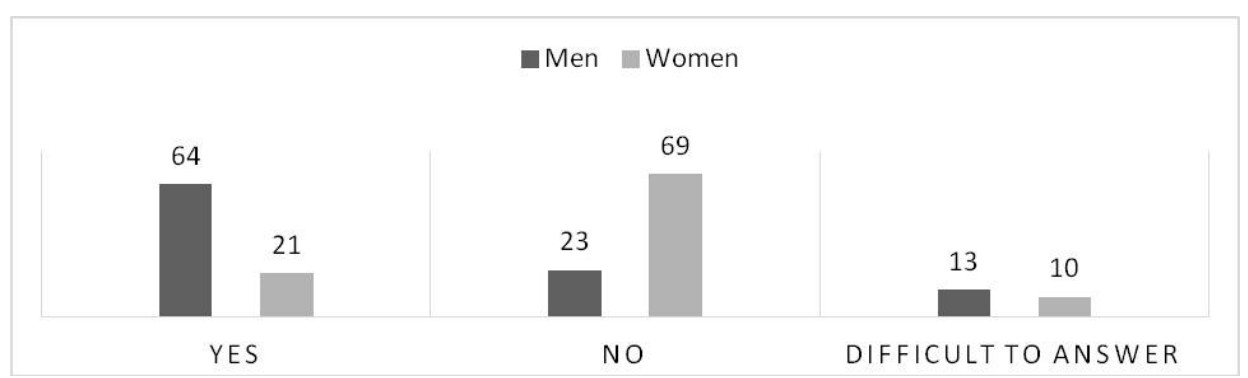

As we can see, most of the female dentists surveyed are dissatisfied with their salary while the picture with men is the opposite. It is noteworthy that among the respondents, doctors with more than 10 years of work experience, who had the opportunity to regulate the conditions and work schedule, responded positively about their income matching to their needs, and among the explanations is that "children grew up", that they have "long-term experience of qualified workers in this institution", and that they hold administrative positions.

For women, the number of working days on average ranged from 10 to 26 per month; $45 \%$ of respondents worked 6 hours a day, $21 \%-8$, and $34 \%-12$ hours. The number of working days for men varied from 22 to 26 per month; $33.8 \%$ worked 6 hours a day, $14.5 \%-8$ hours, and $51.4 \%-12$ hours. At the same time, only $8.3 \%$ of dentists had planned and normative breaks during the working day. Fewer working days for women were associated with childcare and household chores.

Thus, the presented study convincingly shows that the problem of gender in a dental clinic is an objective reality, which is determined both by the presence of unresolved socio-legal and economic issues and by the actual gender differences among dentists.

The next component of the study concerns the health conditions of dentists (men and women). The level of health protection accessible for medical specialists may serve another criterion of equality/inequality of men and women in medicine. General, as well as dental health conditions of dentists, were assessed on a 5-point scale, where 5 means "excellent", 4 - "good", 3 - "average", 2 "poor", and 1 - "unacceptably poor". To the question: "How does your work activity affect your health?", most of the male and female dentists responded negatively. We received the following answers as self-assessment of dentists regarding their general health condition (picture 2). 
General health condition of the dentists as assessed by them (\%)

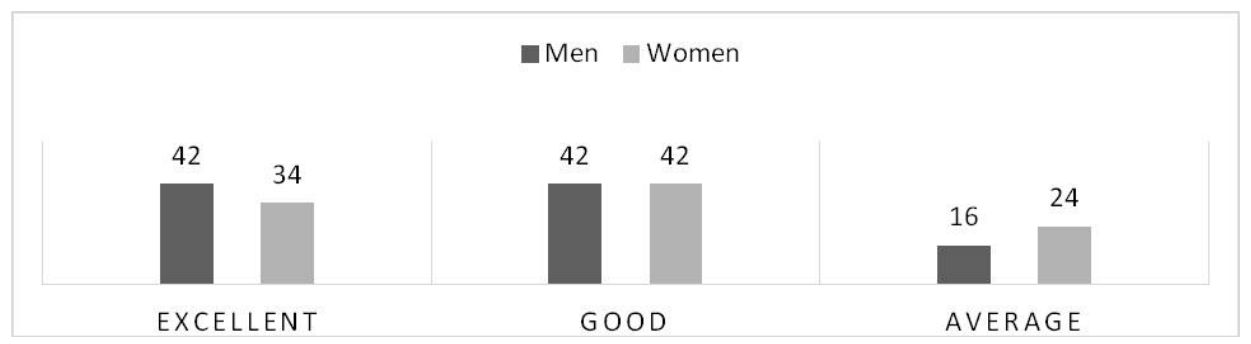

At the same time, dentists, both men, and women mentioned that their health conditions, as well as those external factors accompanying their medical practice, worsened in the last 5 years. In particular, among the factors badly affecting their health, they mentioned forced working posture, eye strain, stress factors, psychoemotional stress, improper and/or untimely nutrition, radiation and noise of devices, some drugs and microbial dust accompanying the mechanical processing of hard tooth tissues, which together badly contribute to pathological changes in the musculoskeletal system (96.7\% of respondents), visual organs $(90 \%)$, hearing, respiratory and nervous systems $(45 \%)$, varicose veins $(35.4 \%)$, the development of dental diseases, weight gain ( $25 \%$ of doctors).

Self-assessment of dental health by dentists gave the following results (picture 3).

Dental health condition of the dentists as assessed by them (\%)

Picture 3

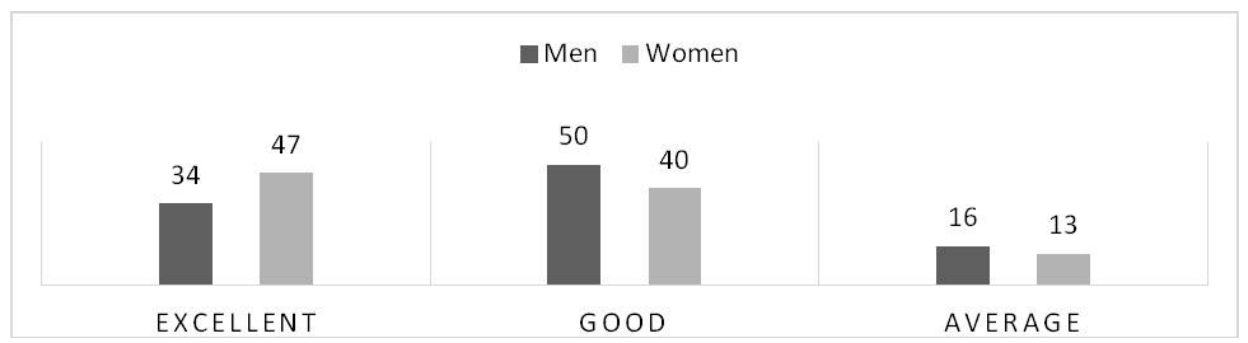

Especially female doctors noted a progressive deterioration in dental health during pregnancy and lactation in the form of hyperesthesia, gum inflammation, the development of multiple caries, and its complications. $56.4 \%$ of females and $41.9 \%$ of male dentists have consulted another dentist in order to prevent dental diseases. Women have applied for dental treatment in $43.5 \%$ of the cases, men in $58 \%$. That is, almost all dentists surveyed used to regularly apply for the prevention and treatment of diseases of organs and tissues of the mouth, which is explained by high professional awareness of the need and effectiveness of therapeutic and preventive work in dentistry.

Thus, according to the results of the study, the work of a dentist can be attributed to a high degree of harmfulness for practicing dentists. Possible nega- 
tive health disorders create an objective background for revision of the working and rest conditions of dentists, and the need to develop and implement improved recommendations for the organization and labor protection of dentists taking into account their special needs as men and women, and making it a part of social responsibility of heads of medical organizations. In addition, for the effective professional work of dentists (both men and women), a genderoriented rational regime of work and rest, physical education, and prevention of occupational diseases are required.

We also tried to reveal the effects of reproduction factors on the work and social status of a female dentist during pregnancy and lactation. It was found that most female dentists during pregnancy were forced to work as usual. They also experienced additional discomfort that aggravated their condition, including inhalation of microbial dust, drug vapors, and the negative effects of ultrasonic devices (82.2\%), which especially adversely affected them in the first trimester of pregnancy. Therefore, $75.8 \%$ of female dentists would prefer to take leave in the first trimester of pregnancy due to the possible negative impact of production factors on the most vulnerable periods of fetal formation. Working during this period, $45.1 \%$ of women-dentists did not have a restroom for staff, and the management of dental organizations did not conduct preventive conversations and measures with them on ergonomics, occupational hazards, and did not provide socially guaranteed recommendations on the norms of the dentists' work during pregnancy.

Maternity leave was paid in full only in $50 \%$ of the cases; in other cases, violations of law by the employer were noted by the respondents, especially in the private sector. Investigating the professional qualities of women after parental leave, it was found put that female dentists, whose maternity leave was longer than a year, experienced a decrease in their professional skills.

At the same time, the majority of women surveyed $(96.7 \%)$ would have taken advantage of the preferential training courses in the period of postmaternity leave. After the maternity period, women would prefer to use their time for additional studies, but at a discount, since all courses for doctors are paid and expensive, and during the maternity period women-doctors are normally deprived of their main income. This problem is also connected with the necessary reduction of working hours because of childcare.

When studying working conditions of dentists, we came to the conclusion that men are more mobile in finding a job, while among women, especially with little children (under 14 years old), the choice of a job was largely determined by the territorial proximity to childcare institutions and schools, as well as by the working schedule available. Therefore, women more often $(66.1 \%)$ than men $(45.2 \%)$ have been forced to endure:

- unsatisfactory working conditions and territorial inconvenience of the medical institution as the workplace,

- outdated and not ergonomic equipment, 
- time limits not proportional to the quantity of patients treated,

- no break time,

- no assistant, and other factors.

Thus, the data presented indicate that in dentistry there is a gender asymmetry experienced mainly by female doctors, which negatively affects professional activity, choice of place of work, competitiveness, physical and psychological health of women-dentists, and, consequently, the state and development of this section of medicine in general.

Key words: sociology of medicine, dentistry, dentist, gender problems, stereotypes, inequality

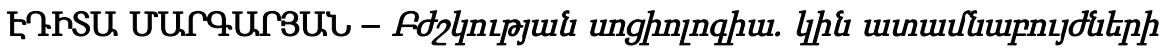

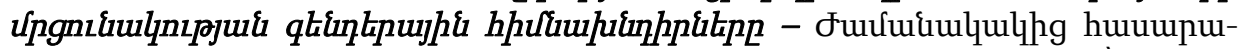

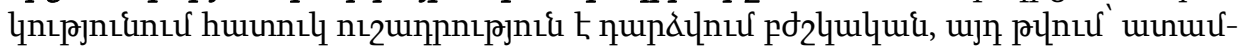

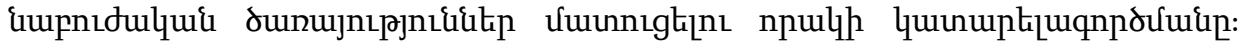

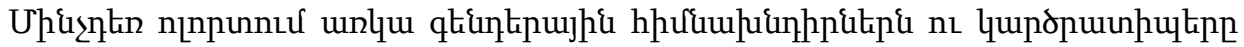
npnzulh

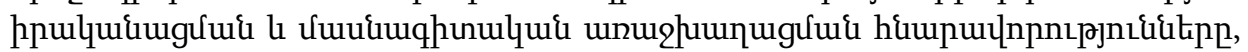

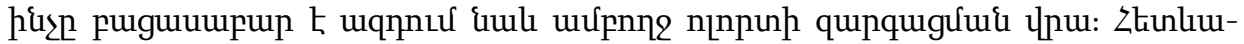

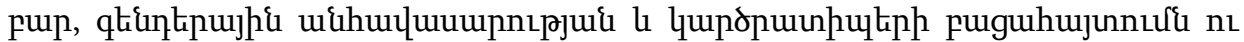

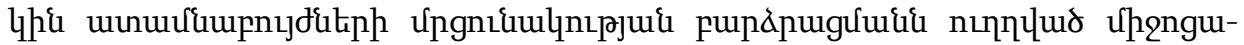

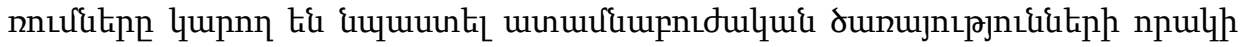

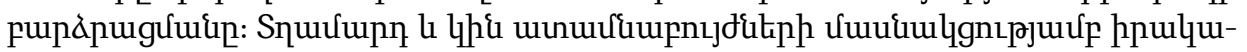

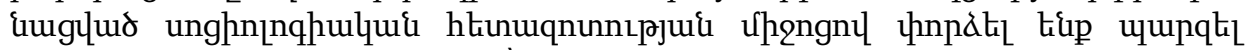

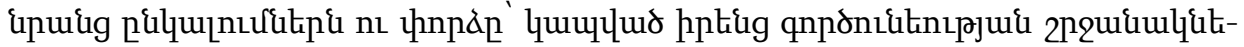

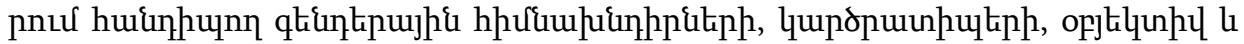

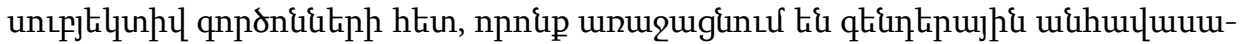

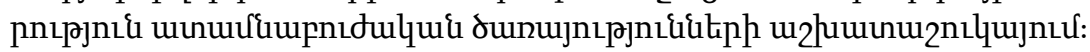

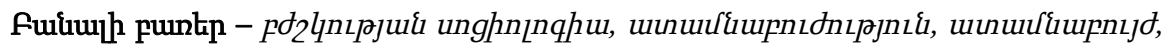

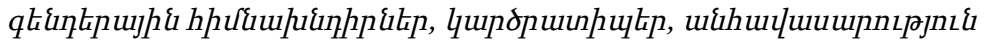

ЭДИТА МАРГАРЯН - Социология медицины: гендерные проблемы конкурентоспособности женцин-стоматологов. - Современная медицина развивается в обществе, в котором особое внимание уделяется качеству оказываемых услуг, в том числе стоматологических. При этом существуют гендерные стереотипы, препятствующие полноценной реализации возможностей женщин-стоматологов как профессионалов, что напрямую влияет на состояние данной области медицины в целом. Изучение гендерного дисбаланса и выработка мер, способствующих повышению конкурентоспособности женщин-стоматологов на современном рынке труда, актуальны на всех этапах организации и оказания стоматологических услуг. В статье выявлены гендерные проблемы и стереотипы на рынке стоматологических услуг через социологический опрос практикующих врачей.

Ключевые слова: сочииология медицины, стоматология, врач-стоматолог, гендерные проблемы, стереотипы, неравенство

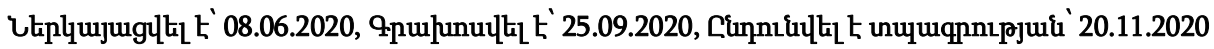




\begin{abstract}
Modern medicine is developing in a society in which special attention is paid to the quality of services provided, including dental services. At the same time, there are gender stereotypes that impede the full realization of the possibilities of women dentists as professionals, which directly affects the state of this field of medicine as a whole. The study of gender imbalance and the development of measures to improve the competitiveness of female dentists in the modern labor market are relevant at all stages of the organization and provision of dental services. The article reveals gender problems and stereotypes in the dental services market through a sociological survey of practicing doctors.
\end{abstract}

Keywords: sociology of medicine, dentistry, dentist, gender problems, stereotypes, inequality

\title{
About Authors
}

Edita Margaryan - Sc. D. in Medical Science, Professor of the Chair of Therapeutic Stomatology, Sechenov First Moscow State Medical University

E mail: edita@mail.ru

\section{REFERENCES}

Levina, V.N. (2016) lichnostnye kachestva vracha v sotrudnichestve s pacientom: uchebnoe posobie, Ijevsk, p. 60

Batyshev, A.S. (2011) Vrach plyus Pacient: filosofiya uspeha, Batyshev A.s., Batysheva T.T., Moskow, VK, p. 521

Kurbatov, A.V., Amlaev, K.R. \& Murav'ev, K.A. (2011) Sovremennoe sostoyanie problemy neravenstva v zdarov'e: ekologicheskie, gendernye, ekonomicheskie aspekty (obzor), Nauka. Innovacii. Technologii, No 74 pp. 24-30

Sud'in, S.A. (2012) Gendernyi aspekt sociologii meditsiny i zdorov'ya, Wenshina v rossiiskom obshestve, No 4 pp. 24-31

Kovaleva, M.D., Vargina, S.A. \& Djereshtieva, M.R. (2009) Gendernye osobennosti razvitiya sovremennoi stomatologii, Sociologiya meditsiny Социология медицины, No 1, pp. 60-62;

Narchaev, M.A., Medjidov, M.N. (2016) Optimizatsiya lechebnoi raboty vrachastomatologa-terapevta na poliklinicheskom prieme, Vestnik Dagestanskoj meditsinskoi akademii No 1(18), pp. 71-74.

Kovaleva, M.D. \& Barkovskaya, A.Yu. (2012) Gendernaya problematika v sotsiologii meditsiny, No 2, pp. 17-18

Makeeva, I.M., Svistunova, E.G., Margaryan E.G. \& Porotsenko, A.S. (2017) Osobennosti trudovoi deyatel'nosti i vozmojnosti professional'nogo rosta vrachei-stomatologov s uchetom ih gendernyh razlichii, Stomatologiya, No 3, p 49 Doi:

https://doi.org/10.17116/stomat201796349-51 